\title{
Distal symphalangism
}

INSERM

\section{Source}

INSERM. (1999). Orphanet: an online rare disease and orphan drug data base. Distal symphalangism. ORPHA:3248

Distal symphalang ism is a very rare bone disorder characterized by ankylosis of the distal interphalangeal joints of the hands and/or feet. 